Marijana Aleksić Glišović1

University ,, Union - Nikola Tesla“ Belgrade

Fakulty of Business and Law

\section{Gorica Jerotijević ${ }^{2}$}

Preschool institution Biseri, Trstenik,

\section{Zoran Jerotijević ${ }^{3}$}

University ,, Union - Nikola Tesla“ Belgrade

Fakulty of Business and Law
SCIENTIFIC REVIEW ARTICLE doi:10.5937/ekonomika1902121A

Received: Jun, 08, 2019

Accepted: Jun, 28, 2019

\title{
MODERN APPROACHES TO EMPLOYEE MOTIVATION
}

\begin{abstract}
Motivation is a process in a person who moves it towards a goal. Given that employees represent the most valuable part of any organization, their motivation is one of the most important management functions. The subject of the work is modern approaches to employee motivation, that is, motivational strategies and tools that can be used for this purpose. The main goal of this paper is to consider a number of issues related to the modern approach to employee motivation: identifying and understanding the factors that motivate employees today, but also ways to increase their job satisfaction. In this paper, modern approaches to employee motivation will be viewed from the aspect of contemporary theories, which include: the theory of righteousness, goal setting theory, the theory of reinforcement and the theory of expectations.
\end{abstract}

Key words: employee motivation theories, modern approach to motivation.

JEL classification:M50, M51, M52.

\section{МОДЕРНИ ПРИСТУПИ МОТИВАЦИЈИ ЗАПОСЛЕНИХ}

\begin{abstract}
Апстракт
Мотивачија је процес у човеку који га покреће према неком ичиљу. С обзиром на то да запослени представљају највреднији део сваке организаичие, юихова мотивисаност представља једну од најзначајнијих функција менаимента. Предмет рада су модерни приступи мотивацији запослених, односно мотивационе стратегије и алати који могу бити коришћени у ту сврху. Главни ичиь овог рада се односи на разматрање низа питања везаних за модерни приступ мотивацији запослених: идентификовање и разумевање фактора који мотивишу запослене данас, али и начина за повећање юиховог
\end{abstract}

\footnotetext{
${ }^{1}$ marijana.aleksic@yahoo.com

22 goricavidic.ts@gmail.com

${ }^{3}$ zoranjerotijevic@gmail.com
} 
задовољства на раду. У раду ће се модерни приступ и мотивација запослених посматрати са аспекта савремених теорија у које спадају: теорија праведности, теорија постављањ и ицьа, теорија појачавањ а и теорија очекивања.

Кључне речи: теорије мотиващије запослених, модерни приступ мотиваuุијu.

\section{Introduction}

"The art of selecting people is not nearly as difficult as art to enable the chosen ones to develop their full potential." Napoleon Bonaparta. Motivating yourself is difficult, and motivating others is even more difficult. With this in mind, the question arises what determines employee motivation and how to fully utilize its capabilities in order to develop the organization? Motivation, according to many definitions, is an intrinsic enthusiasm for an employee and an effort to achieve work-related activities, that is, internal force that encourages individuals to achieve personal and organizational goals. In essence, it comes down to the inner drive and level of energy that determines the individual to decide to take action - and this is usually a positive action directed towards growth, progress and general or direct improvement of conditions or effects.

The notion of motivation is related to the Latin word: movers or shifts and the harshest can be described as targeted behavior bearing in mind that people are motivated in situations when after the action they expect the achievement of a goal and a prize that will meet their needs. "Work motivation proved to be one of the most important assumptions of the effectiveness of work and the achievement of the given goals of both individuals and the whole organization "(Boljanović, Pavić, 2011, p. 251). Motivation is a process that takes place within the person, which affects the degree, direction and duration of the effort involved in achieving a goal (Greenberg, Baron, 2003, p. 41). Motivation refers to some aspect of life that exists in the consciousness and behavior of each person and it launches to action, and the task of human resources managers is to find a way to understand how to inspire and ensure a high level of employee motivation, bearing in mind that their motivation is influenced many factors: biological, intellectual, economic, social, emotional ... because every employee perceives different activities, events, people and goals as motivating. It is precisely because of this complexity that the motivation of an employee must be regarded as an internal driving force subject to the influence of both internal and external factors. Motivation for employees is a combination of meeting the needs and expectations of work and factors at the workplace that enable their motivation.

Albert Einstein spoke of the weakness of the attitude, becoming a weakness in character. Transferred to an organization - if employees have a negative attitude or show inactive behavior, they will become unmotivated and, consequently, unproductive. The organization's human resources management, among other things, must provide an incentive environment that creates motivated workers. Therefore, although they are well acquainted with traditional, tried and tested theories and approaches, they must be in the process of up-to-date and most useful methods and techniques of motivation, but also brave enough to apply new ways of motivating their workers. 


\section{Process theory of motivation}

This paper presents some of the modern motivational theories in the business world, in which motive is the key to success, since people are the most important and most challenging resource of the organization. Employees who are motivated and working hard to achieve their personal and organizational goals can become a crucial competitive advantage for the company. Therefore, it is so important to understand the process of motivation, what motivates individuals, and how the organization can create a workplace that enables employees to do the best they can.

In the development process, the first managers laid the foundations that made it possible for today's managers to better understand their employees and how to best motivate them. Since then, new theories have made it possible to gain a better approach and understand the essence of employee motivation. There are four modern motivation theories that provide an insight into the improvement of employee performance: theory of expectations, theory of justice, goal setting theory, and theory of reinforcement. They are often referred to as process theories, all of which range from engaging employees in an activity if they expect some benefit. Hence, the activity being undertaken is an instrument for achieving certain goals that will give the employee the benefit he expects. These theories are based on the fact that an employee chooses a particular type of behavior depending on how he estimates that the results of this behavior will work to achieve the goals. It should be noted that since employees have different preferences towards different goals, in each individual situation, employee motivation is a combination of the interaction of individual expectations and preferences.

The Theory of Equity - developed by J. Stacey Adams, is based on a simple assumption that people in the organization want to be treated fairly (Moorhead, Griffin, 2004 , p. 76) and is based on the perception of an employee about how he is treated in a relationship to associates. Equality means equity, and in the workplace it refers to the perceived equality of employees according to the way they are treated and according to the rewards they deserve. Employees estimate their own outcomes (in the form of salaries or benefits) in relation to their contributions to the organization (in terms of hours of work, education, mastered training, etc.), and then compare the outcome and contribution relationship with one of the following experiences:

- previous experience of an employee in a different position within a given organization,

- previous experience of an employee within another organization,

- $\quad$ previous experience of another employee within a given organization, or

- $\quad$ previous experience of another employee within another organization.

According to the Adams Equity Theory, if an employee finds out that there is inequality, they will most likely make one of the following choices:

- will change their working habits (less effort at work),

- will change its requirements related to compensation for work or income (it will demand an increase, shorter working hours for the same salary),

- he develops a distorted perception of himself, which calls into question his self-esteem and self-image ("I have always thought I'm smart, but now I realize that I am / I'm not much smarter than my colleagues"), 
- develop distorted perception of others (“Anina’s position is much less / more flexible than mine"),

- $\quad$ will treat the situation of inequality from a different perspective ("maybe I'm not working hard as other sector leaders, but I'm working far more than most graphic designers"), or will

- $\quad$ abandon a situation in which they recognized the existence of inequalities (leaving a specific job position within the organization or the organization itself).

Bearing in mind that the motivation of an employee does not depend solely on the award but primarily on the relationship of the effort invested and the rewards it receives, it is clear that employees will compare their relationship of effort and rewards with the relationship of effort and rewards of the reference persons in the organization and / or environment. On the basis of this comparison, an employee's perception of fairness or unfairness of the prize is formed, and a balanced relationship of commitment and rewards of all employees is perceived as just. According to Festinger (1954, according to Jelić, 2009), it is not necessary for people to tell others what they are in their eyes, but only enough to compare each other. Consequently, unjust or unequal distribution of prizes will have a demotivating effect on the employee, who perceives this inequality in the context of overpaid or subsistence.

However, one should not ignore the human nature, that is, the inclination of employees to overestimate their personal contributions or rewards to other employees, which leads to the creation of unrealistic images, which is one of the problems of applying this theory. However, human resources managers can use this theory in order to improve employee satisfaction - bearing in mind that everyone wants an equal and just treatment, management must make an effort to understand the perception of honesty by employees and, in line with this, take appropriate steps to reduce the situation in which are inequalities.

The Theory of Reinforcement was developed by Harvard psychologist B. F. Skinner. This approach is called positive reinforcement or modification of behavior, and is based on the fact that employees can be motivated by the adequate design of the work environment and rewards for the results achieved, as the accent on punishment yields negative results. The approach is reduced to the assumption that employees take certain activities because they know what the consequences of these activities are, and depending on what consequences they follow, they adopt certain behavior or avoid it. There are three basic types of consequences that follow after the undertaken activities: positive, negative and none. In general, positive rewards are considered rewards, as opposed to them - punishment is all that suppresses and does not encourage any behavior. Motivation of employees who rely on the theory of reinforcement, although actually simple, can be effective because it is functional - all of its components are defined by their function, and not their structure, which means that the consequences can work differently for different people and in different situations. What a punishment for an employee can actually be a reward for someone else, and that's why managers use this theory in practice to motivate and direct employees to desired types of behavior by using rewards to achieve the desired results. The strength of this Skiner theory lies in its overlap with the requirements of good governance, since it emphasizes the removal of 
obstacles to achieving the goal, careful planning and organizing, feedback control, and constant communication (Weihrich, Koontz, 1998, p.)

Goal Setting Theory. Edwin Locke developed the theory at the center of the intent to achieve a goal as the main source of labor motivation, (Moorhead, Griffin, 2004, p. 96) and is based on the premise that the intention of an employee is to direct his work to the goal, the primary source of motivation . When setting the goal of an employee, it becomes clear what needs to be achieved and how much effort will be needed to complete it. This theory has three main components: (Janićijević, 2009, p. 42)

- $\quad$ specific goals lead to a higher level of performance than the more general goals ("do your best", "do the best you can"),

- The more difficult goals of the water have a better effect than easy goals (provided the employee accepts the goal),

- $\quad$ Progressive feedback on the goal improves performance, they are particularly important because they help the employee to see the gap between real performance and ideals (the desired outcome as a goal).

Bearing in mind the trend towards empowerment of employees at the workplace, more and more employees participate in the goal setting process. This theory starts from clearly defined and defined goals in order to motivate employees to achieve goals of the company easier, faster and more efficiently. The work process may be known to the worker, but if he does not know the purpose for which he is doing the job, the motivation will be low.

Victor Vroom's Expectancy theory (1964) is one of the most widely accepted motivation theories, according to which expectations are based on the probability that an employee works in a certain way, which depends on the strength of an employee's belief that this act will produce a certain outcome that he values. This theory attempts to figure out why a person chooses a certain form of behavior in a particular situation. The theory of expectation is one of the best and most widely accepted motivation theories, and its emphasis is on the relation between the motivation of the employee and his behavior. According to this theory, the probability that employees will work in a certain way depends on the strength of his belief that this action will produce a certain outcome and whether and how much that outcome will be valued. The degree of employee motivation depends on three important links:

- The relationship between effort and performance, ie the strength of an individual's expectation that certain effort will lead to a certain level of performance,

- The relationship between the effect and the outcome, ie the power of expectation that a certain level of effect will lead to a certain outcome,

- The relationship between outcomes and individual needs, i.e. to what extent the level of expected outcome can satisfy the employee's personal needs.

The Expectancy Theory (Koonz, Weihrich, 1998, p. 6) includes concepts:

- Valence refers to the attractiveness of the prize and can be positive, negative or indifferent, depending on what the employee's activity would produce. Valenca refers to the affective orientation of the employee to the outcome, that is the degree of attractiveness, the importance of the outcome for an employee and, consequently, it is subjective, because it depends on the personality and 
its relation to some consequence (outcome).

- Instrumentality is activity in the direction of achieving the desired outcome. It offers an answer to the question of why certain outcomes are important to employees and from where they have a positive or negative valency. Outcomes can have valency also due to the expected connection with some future outcomes in the future (promotion can have a positive valency for a worker, not only because of getting to a new, better job, but also because he will bring him a higher salary or more autonomy in work). If this logic moves backwards, the build-up of the trail builds up at work leading to improvement, which in turn leads to higher pay.

Although this theory suffers from criticism because people do not always decide rationally by making possible favorable results, but often with impulsive, emotional and irrational reactions in the desire for results at all costs, the significance of this theory should be recognized, which lies in the linking of efforts in work and realization desired goals.

- Expectation is the level of belief in the possibility of achieving the desired goals by undertaking a certain activity. As with instrumentality, expectation is one type of perception of probability that an effort will lead to the desired result. It can move in values between 0 and 1 .

According to Janićijević N. (2009, p. 45) the motivation of employees is determined by the following three types of relationships:

Effort - performance (1st row score),

Performance - prizes (2nd order score),

Prizes - personal goals of an employee.

In order for a worker to be motivated, he must first of all believe that if he works, he will succeed in achieving the desired result, i.e. that they will achieve an effect that will earn a certain prize. An employee must believe that he / she will really receive the reward he / she is valued for. The expectation theory essentially speaks of the fact that employees will not be motivated to work if they do not believe that, if they invest, they will be able to achieve the effect for which the reward will follow. According to this theory, one of the reasons for lack of motivation lies in the belief of the workers that they will be manipulated in such a way that even if they achieve the required effect, the prize will be absent. The reason for the lack of employee motivation can be the prize itself, because if a reward for performance transfer is offered something that an employee does not want or does not value, then accordingly, he will not be motivated to work in order to reach such a prize.

Goal setting theory is based on employees perceptions of what their treatment is in relation to their associates. Goal Setting Theory suggests that employees are highly motivated to work when specific goals are set and when they have feedback about their progress. The theory of reinforcement claims that behavior is a function of consequences, that is, that people take actions because they know what they can expect as a result. The expectation theory is based on the expectation of the worker that his invested effort through concrete activity will result in achieving the desired goal. These four process theories build on content theories in that they eliminate their main defect, which is reflected in the lack of answers to the question why people often undertake 
certain actions that are not expensive to them, i.e. which are contrary to their interests and motives.

\section{How to modify existing jobs in order to increase employee motivation?}

There are a number of different methods of motivating employees and their combinations, yet some strategies prevail in organizations that seek to improve the motivation of employees. Given that the field of human resources management is characterized by dynamic development, many theoretical and practical knowledge is quickly overcome, but one thing is certain: human resources are not only a mere sum of employees, but are also understood to mean "the total human potentials: available knowledge and experience, possible abilities and skills, possible ideas and creations, degree of motivation and interest in achieving organizational goals and the like "(Kulić, 2005, p.86). Understanding what motivates employees is the first step towards increasing their motivation to work, and inevitably affect the productivity and performance of the organization. It is clear that organizations can achieve an improvement in their performance by investing in employees. Since in the same sector of one organization workers are driven by different motivators, the assumption is that the key is found in a combination of flexibility, job design and rewarding systems. Numerous theoreticians and many scientific research have contributed to today's understanding of employee motivation. Nevertheless, it is necessary to mention some of the ways in which these concepts can be practically applied today in the workplace in order to achieve the goals of organizing and improving individual effects.

Motivational design of the work Human resources management can, through the modification of existing jobs, increase the motivation of workers through:

Extension of the work related to the horizontal expansion of the work, that is, the increase in the number and variety of tasks performed by the employee. With a greater diversity of tasks it can be expected increased employee satisfaction with work, especially in situations where it is a matter of uniform, repetitive tasks. The disadvantage of this concept lies in the assumption that employees can experience that they are required to do more, without changing the fee, which can produce dissatisfaction and reduced motivation for work.

Job enrichment refers to the vertical expansion of an employee's work. Bearing in mind that the expansion of the business refers to the width, ie, the scope of work, enriching a job is a way to increase the depth of work by giving the employee greater autonomy, responsibility and decision-making powers. In this environment, the employee is given the opportunity to use his talents and skills, but also has greater control over planning, implementation and control of work tasks. Essentially, enriching the work leads to increased job satisfaction and reduced absenteeism.

Changing a job is also called cross-training or job rotation, and relates to the transfer of employees from one job to another. This can be done to expand the knowledge workers' corpus or because their reduced motivation to a specific job is noticed. The shift or rotation of work leads to increased flexibility in planning and production, and is also of great importance in the training of lower level managers in different functional areas. The disadvantages of this concept are related to the increase in training costs and the 
period of reduced productivity that is needed while employees do not reach a satisfactory level in new work areas.

Work planning options. In an effort to meet the needs for diverse workforce and at the same time to retain the best employees, maintaining and improving their competitiveness, organizations are faced with challenges in finding new ways to motivate their employees. Many workers have a problem to match work and private life, or to achieve a satisfactory quality of life outside working hours. This concern occurs even when the employee is in the workplace and can affect the reduction of their motivation and productivity. Organizations that have introduced flexible arrangements for employees have acquired motivated employees whose productivity has increased. There are increasingly popular alternatives to traditional work schedules, such as flexible working hours, a compressed or four-day working week, remote work and work sharing, as a way for employees to focus on the job they need to do, without compromising the quality of their private lives, which certainly leads to greater motivation for work.

Flexible working time allows employees to decide when to work. They are expected to work for a certain number of hours per week, but have the ability to independently allocate the number of hours worked during the week / month, i.e. when they come to work and when they leave.

One of the options for workers who want to provide themselves with maximum free time, three-day weekends or to avoid travel to work and work in morning and afternoon traffic jams is a compressed or four-day working week. This is a concept where employees work for 40 working hours, but by deploying them in a way that they have a shorter working week. The most common arrangement is the 4-40 ratio, ie the regime in which the employee works four ten-hour days a week. Organizations that have this option of organizing work recognize the advantage of this regime in the form of increased motivation and productivity and reduced absenteeism from work.

Remote work is a work scheduling option that provides workers with the opportunity to work from home, through a computer connected to their office, headquarters or colleagues.

Job sharing is the ability to do the job in a way that two employees share assignments, responsibilities, and working hours of one workplace from 40 hours a week. In practice, it is used much less than flexible working hours and a compressed working week, although these employees provide work flexibility, while the organization receives "two for the price of one" or two workers, and therefore two sets of skills and abilities to achieve one set of goals.

Organizations often use a combination of these scheduling options depending on the needs and the specific situation. The point is that employees who have more free time or autonomy to organize their own time in an opportunity to lead a balanced life, which gives the opportunity to be happier and more productive. Although each of these job scheduling options may also have some disadvantages, the benefits outweigh the problems far beyond, and this is supported by the fact that the number of organizations offering more flexible work opportunities has a growth trend.

Recognition of commitment, recognition and empowerment - each worker has his own unique, unique needs that he seeks to satisfy through work. For this reason, organizations must create a range of different incentives that will cover a wide range of employee needs within the work environment, which should lead to an increase 
in the level of employee motivation. Recognition and formal recognition for the top efforts of an employee or group of workers is one of the ways to increase their motivation. Recognition is a form of positive feedback that is a signal to employees that the organization recognizes and values their contribution. Recognitions can take various forms - formal and non-formal, so some organizations have a tradition of official ceremonies to award prizes and celebrate achievements of workers, while others through informal interaction congratulate employees on a well-done job. Recognition can also be in the form of a cash prize, an increased number of free days, greeting cards via e-mail, gifts or oral praise. However, it should be noted that it is not necessary that the recognition comes solely from superiors to be effective. Employee empowerment, also called the inclusion of employees, ie participatory management, refers to delegation of decision-making powers to employees at all levels of the organization. In this way, workers are given greater responsibility for planning, implementing and controlling the results of their decisions, and this type of empowerment is based on the assumption that human resources, in particular at lower levels in the firm, represent underused resources. Essentially, employees are able to contribute much more to their organization's skills and abilities if they are given the opportunity to be part of the decision-making process and provide access to resources that are necessary for the implementation of their decisions. As a result of employee empowerment, feelings of frustration are reduced, work motivation increases, and energy is diverted from self-sustainability to better performing business tasks.

Financial Incentives - Every comprehensive approach to employee motivation must also have a component of cash incentives to improve performance. Despite the existence of a large number of alternative motivators, money still takes an important place among them. Money is effective when it is directly related to the ideas or achievements of an employee. However, if they are not related to other, non-monetary motivators, its motivational effects are short-lived, and may also be counterproductive unless they are equally accessible to all members of the organization. Modern organizations use a number of pay-per-pay / pay-per-action programs, profit sharing, team split plans, option options and bonuses to motivate employees for work and productivity. The standard concept of wages or wages per hour is increasingly confusing the concept of variable wages, which means that one part of the salary of the employee is directly linked to his performance. Financial incentives are reduced to the variability of compensation that is proportionate to the employee's contribution, and are also known as pay-per-action programs.

The pay-per-pay / pay system implies that employees are paid a certain amount for each unit they produce, in this way the worker can bring in the earned amount of the earned amount with its productivity.

Profit sharing is based on the overall profitability of the company, and using certain formulas, management forms part of the profits of the organization to all employees.

Wage Sharing Plans are incentive-based schemes based on group productivity where employees within a team share a financial gain attributable to the increased productivity of that team. In this way, workers are motivated to increase productivity within their working group, unrelated to the general picture of profit for the organization as a whole.

One of the popular approaches to financial incentives is the allocation of stocks or the provision of opportunities for employees to buy a certain amount of stocks at prices 
below the market - which can be a strong motivator given that those who receive shares receive a chance to earn more money from them.

Bonus is nevertheless the most popular form of incentive, it is a one-time cash prize that employees receive to achieve a certain level of performance. The bonus system of the organization compensates employees for a good job while motivating and encouraging such behavior in the future. This is because bonuses may vary depending on the outcome.

Learning, creativity and innovation, if employees offer tools and provide opportunities to achieve more, most will use them. Organizations can motivate employees to achieve more in such a way that they will commit themselves to continuously improving employees' skills. Programs of various trainings and trainings for employees are increasingly popular and more efficient ways to increase the knowledge and motivation of employees, and through these programs the employees' self-confidence increases. Observed from the motivation motivation of the employee - if the acquired knowledge can be applied to the job to be done, acquiring that knowledge will be a value for both the employee and the organization. Within the organization, an irreplaceable number of employees of great creative and innovative potential, who do not offer management with fear of being ignored or smuggled, do the job. For this reason, it is important from the aspect of employee motivation to provide opportunities for workers to use their ideas, because the power of creation is motivated and at the same time it benefits the organization as the exchange of ideas and information among employees and sectors increases. These improvements in terms of promoting creativity and employee innovation create an environment that is open to change that can give the organization a competitive edge in the market.

Using some of the above-mentioned motivation methods and tools, in accordance with the requirements of a specific situation, managers can redesign existing jobs to increase the motivation of their employees. Horizontal expansion of the work implies an increase in the number and variety of tasks the worker performs, and a greater diversity of work tasks leads to increased job satisfaction, and consequently to an increase in employee motivation, especially when it comes to repetitive jobs. Job enrichment is a vertical expansion of the work and enables the employee to have more autonomy, responsibility and decision-making power. Other motivation tools relate to work planning options, recognition programs, recognition and empowerment of employees, and financial incentive programs. Non-financial incentives are compulsory companion of financial incentives that through their synergy, the effect of high motivation of the employee is permanent. Bearing in mind that material incentives are strong but shortterm, and therefore insufficient motivators, non-financial motivators encourage team spirit and include recognition, responsibility and progress. Managers who recognize and promote participatory environments treat employees with respect and show them that they have confidence in increasing employee motivation. In the long run, sincere praise and personal gestures are far more efficient and economical than the awards themselves, but certainly the programs that combine cash prize systems with the provision of opportunities for employees to satisfy the needs for self-realization, the most powerful motivators. 


\section{A modern approach to motivation}

Daniel Pink (2009), in the context of a modern approach to employee motivation, puts emphasis on the extreme mismatch between the practice of motivating the employees that the organizations use and the practices that really work, that is, how the ways of motivating employees can be updated to give the highest motivation and productivity of workers. The practice of motivating Pinka is based on the theory of self-determination that claims that all human beings possess an innate ability to be autonomous, selfdetermined and interconnected, and that when this synergy is achieved, people achieve higher productivity at the same time, living more quality. Modern approach to motivation focuses on intrinsic motivation, that is, the joy of the task itself, bearing in mind that human beings have an "inherent tendency to seek new challenges, to expand and use their abilities, to explore and learn" (Pink, 2009, p. 8). Accordingly, organizations should review existing approaches to motivation in a way that will match them with modern business environment and challenges, or, when managing human resources, focus on the innate need of workers to direct their own lives (autonomy), to learn and create new ones things (mastery), and make themselves and the environment better (purpose).

Autonomy - refers to enabling decision-making autonomy in relation to some or all of the main aspects of work:

When they work (time) - the work environment needs to focus on achieving the results, rather than on the time of work, thus enabling employees to have flexibility within the deadline for performing the task.

How they work (technique) - The employees should be given initial guidelines, but they should be able to implement the project in a way that they consider appropriate rather than by a strict procedure.

With whom they work (team) - employees should be given some kind of choice in relation to who they are working with. Certainly not workers from every working position are competent to perform the recruitment process, but when there is an opportunity there should be a possibility for them to perform the tasks they perform within independently assembled teams.

What they do (task) - employees should be allowed to do so. "creative" days when they will be able to enrich their experiences and knowledge by working on a task that specifically inspires them. The autonomy of the task is based on empirical evidence that many new initiatives are created precisely during this "creative free time".

Mastery - refers to providing the opportunity for employees to become better in what matters to them, by offering them work assignments that are neither too difficult nor too simple and which as such enable employees to expand and develop their skills. The risk of giving a job that does not meet the capability of an employee can be a lack of motivation and boredom, but also providing tasks that go beyond the capabilities of employees can result in a decline in motivation and anxiety.

The purpose - relies on the natural desire of employees to contribute to the creation of something that will be greater and lasting than themselves. Employees need to communicate their goals with the superiors, in that way they will understand the goals of the organization, and when they understand the purpose and vision of the organization, they will be able to determine their role in achieving this purpose, which will make them happy in their work. Organizational and individual goals must be harmonized so that the employees of the organization can be experienced as a unique team. 


\section{Conclusion}

Recognizing the importance of motivation for work, management organizations are making great efforts to better understand and understand the phenomena that form the basis of man's need to create, to develop, to progress. The level of motivation of employees is actually a topic that both theoreticians and practitioners approach with increasing interest, since the motivation of employees occupies a significant place in the research of organizational behavior. Today, the focus of the researcher focuses on intrinsic criteria for job satisfaction, where, apart from the personality trait, attention is focused on examining the impact of the organization and family balance on the motivation of the employee, or in general to his satisfaction with the quality of life.

Modern motivation theories indicate that the motivation that employees feel about their work is less related to material rewards and more to the job design itself. As a result, initiatives for expansion, ie "enrichment of work", have been used as key terms: empowerment, creativity and innovation, flexibility, autonomy, intrinsic motivation, team work...

Motivation of employees represents the level of energy, dedication and creativity that the employees of the organization bring to their jobs. Motivated employees help organizations to survive and advance, they are more dynamic and productive, but realizing the importance of employee motivation raises the question of how to enable it in the context of modern fast-changing jobs. The starting point of each manager is to see and understand what motivates employees in the context of the roles they perform, because of all the functions that the manager does, motivation of employees is certainly the most complex, given the fact that what motivates employees is constantly changing.

\section{References}

Armstrong,M. (2001). A Handbook of Human resource Management Practice, (8th Edition), London: Kogan Page.

Bilton, K. (2010). Menadžmentikreativnost, Klio, Beograd, str. 28.

Bogićević, B. (2017). Menadžmentljudskihresursa, EkonomskifakultetUniverziteta u Beogradu.

Boljanović, J.Đ., Pavić, Ž.S. (2011). Osnovemenadžmentaljudskihresursa, UniverzitetSingidunum, Beograd. str. 251.

Boselie, P. (2010). Strategic Human Resource Managment - A Balanced approach, McGraw-Hill, New York.

Buble, M. (2000). Menadžment, Ekonomskifakultet u Splitu, Split.

Carrell,M., Elbert,N., Hatfield,R. (2000). Human Resource Management: strategies for Managing a Diverse and Global Workforce, (sixth Edition). London: Dryden Press-a division of Harcourt College Publishers.

Coulter, М.(2008). Стратегијскименаџментнаделу, Датастатус, Београд.

Greenberg, J., Baron, R,A. (2003). Behavior in Organizations, New Jersey: Pearson Education, Inc.str.41. 
Huczynski, A., D. Buchanan., (2013). OrganizationalBehaviour An introductory text,Fourth Edition,FT Prentice Hall FINANCIAL TIMES,Pearson Education.

Janićijević, N. (2009). Organizacionoponašanje, Data status, Beograd, str. 45.

Jelić, M. (2009). Štavidimo u ogledalu? Pojam o sebiisamopoštovanje, Školskaknjiga, Zagreb.

Koontz, H., Weihrich, H. (1998). Менеџмент, MATE,Загреб,UDK 658, стр. 124.

Kulić, Ž. (2005). Upravljanjeljudskimpotencijalima, Radničkaštampa, Beograd, стр. 86.

Lukić, T. (2014). Uticajedukacijeiorganizacionekulturenakreativnostiinovativnost, doktorskadisertacija, UniverzitetSingidunum, Departmanzapostdiplomskestudij eimeđunarodnusaradnju, Beograd, str. 150 .

M,Gagne. (2014).The Oxford Handbook of Work Engagement, Motivation, and Selfdetermination theory, Oxford University Press.

Marchington, M., Wilkinson, A. (2005). Human resource management at work, Londnon: Chartered Institute of Personnel and Development.

McShane.,VonGlino.(2002). Organizational Behaviour, Second Edition, London: McGraw-Hill.

Miljković, S. (2007). Autorskitekst: Motivacijazaposlenihimodifikovanjeponašanja u zdravstvenimorganizacijama, ActaMedicaMediana, Niš.

Moorhead, G., Griffin, R,W. (2004). Organizational behavior. Managing People and Organizations, Boston: Houghton Mifflin Company.str.76.

Pink,D.(2009). Drive: The Surprising Truth About What Motivates Us, Riverhead Books, str.8.

Todosijević, R. (2015). Promene u strategijskommenadžmentuizazvaneinovacijamaik ljučnimtehnologijama, AnaliEkonomskogfakulteta u Subotici, br. 34.

Torrington, D., Hall,L., Taylor,S., Atkinson, C. (2009). Fundamentals of Human resource Managment. Managing People at work, Prentice Hall.

Wigfield, A; J,S,Eccles. (2000). Publication:Contemporary Educational Psychology, Elsevier. 